\title{
Multiple mechanisms in which agricultural insects respond to environmental stressors: canalization, plasticity and evolution
}

\author{
Múltiples mecanismos con los que los insectos de ecosistemas agrícolas responden \\ a estresores ambientales: canalización, plasticidad y evolución
}

Yeisson Gutiérrez ${ }^{1}$

\begin{tabular}{ll}
\hline \multicolumn{1}{c}{ ARTICLE DATA } \\
\hline 1 Research. Ph.D. Centro de Bioinformática y Biología \\
Computacional de Colombia - BIOS. Colombia, gutier- \\
rez.yeisson@gmail.com.
\end{tabular}

Cite: Gutierrez, Y. (2020). Multiple mechanisms in which insects respond to environmental stressors: canalization, plasticity and evolution. Revista de Ciencias Agrícolas. 37(2):90-99.

doi: https://doi.org/10.22267/rcia.203701.129

Received: March 112020.

Accepted: May 022020.

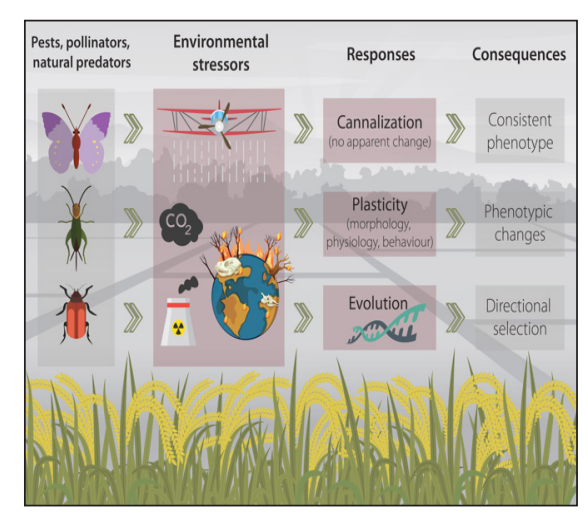
\begin{abstract}
Insects are a paramount component of biodiversity in terms of taxonomic richness, ecological functions and ecosystem services. However, many human activities have negative consequences on such organisms, causing changes in their morphology, physiology, behaviour, and even causing mass deaths leading to the wellrecognized insect decline phenomenon. Although the effects of some environmental stressors (e.g. global warming and pesticides) on insect biology are fairly well understood, there is a plethora of stressors that that have only recently been considered. Additionally, although the exposure to multiple stressors is a common scenario in natural conditions, our knowledge on insect responses in this regard is still incipient. Knowledge that is in much need to inform policy makers in the fight against global change. Here, a short review on prominent environmental stressors, and the known responses that insects may exhibit, which are summarized as canalization, plasticity and evolution is provided. Furthermore, an outlook and recommendation for future studies aiming to elucidate the effects of environmental stressors (both lone and mixed) on insect biology is given. This manuscript advocates for controlled (lab or semi-field) manipulative experiments that implement realistic environmental conditions and that ideally combine several stressors.
\end{abstract}

Key-words: decline; global change; insecticide resistance; pesticides; plasticity; pollinators; pollution.

\section{RESUMEN}

Los insectos son un componente primordial de la biodiversidad en términos de riqueza taxonómica, funciones ecológicas y servicios ecosistémicos. Sin embargo, muchas actividades humanas tienen consecuencias negativas en tales organismos, causando cambios en su morfología, fisiología, comportamiento e incluso causando muertes 
masivas que conducen al fenómeno bien conocido de disminución de insectos. Aunque los efectos de algunos estresores ambientales (ej. el calentamiento global y los pesticidas) sobre la biología de los insectos se conocen bastante bien, hay una gran cantidad de estresores que solo se han empezado a considerar recientemente. Además, aunque la exposición a múltiples estresores es un escenario común en condiciones naturales, nuestro conocimiento sobre las respuestas de los insectos a este fenómeno es aún incipiente. Conocimiento que es muy necesario para informar a los responsables de la toma de decisiones políticas en la lucha contra el cambio global. En este artículo, proporciono una breve revisión sobre estresores ambientales de gran importancia y las respuestas reconocidas que los insectos pueden presentar, que se resumen como canalización, plasticidad y evolución. Además, proporciono perspectivas y recomendaciones para futuros estudios con el objetivo de dilucidar los efectos de los estresores ambientales (tanto solos como en combinación) sobre la biología de los insectos. Propongo la realización de experimentos manipulados controlados (laboratorio o semi-campo) que implementen condiciones ambientales realistas y que combinen idealmente varios factores estresantes.

Palabras clave: disminución de insectos; cambio global; resistencia a insecticidas; pesticidas; plasticidad; polinizadores; contaminación.

\section{INTRODUCTION}

Insects are of extreme ecological relevance because of their enormous diversity and their important role as providers of ecosystem services and in ecosystem functioning (Losey and Vaughan, 2006; Weisser and Siemann, 2008; Cardinale et al., 2012). Insects have as well economic and medical significance as a wide range of agricultural pests, invasive organisms and disease vectors are insects species (Smith, 1973; Pimentel et al., 2005; Costanza et al., 2011). For instance, it was estimated that the annual control of a single insect pest species can cost as much as US\$ 5 billion (Zalucki et al., 2012).

Nowadays, insects are a matter of debate in several topics of broad scientific and public interest. On the one hand, the decline of naturally occurring insect populations has raised awareness about the urge to preserve natural habitats and reduce the factors that cause these negative effects (Potts et al., 2010; Hallmann et al., 2017; Sánchez-Bayo and Wyckhuys, 2019). On the other hand, ongoing global spread of pest and invasive insect species impose a challenge for agricultural production (Bebber et al., 2014; Luque et al., 2014). In particular, crop losses to insect pests can be as high as 80\% of the production (Oerke, 2006). In addition to the topics mentioned above, insect are also a current topic in the food-production industry as a vast amount of studies propose massreared insects as a viable alternative source of proteins for animal and human consumption (Van Huis, 2013). Studies in this matter range from rearing techniques, up to nutrient content and perception of the product by the consumer (Megido et al., 2016; Barsics et al., 2017).

All the aforementioned arguments on the current importance of insects support the need to deepen the understanding of responses that these outstanding organisms (i.e. insects) may elicit to stressors and ongoing environmental changes. An interesting example of the impact that insect responses can have on the humanenvironment interaction is the termed "pollinator crisis" (i.e. decline of honey bee and bumble bee populations). This phenomenon is occurring at a global scale and has motivated changes in the legislation of several countries in an attempt to control or reduce the major stressors that may be causing this critical situation (e.g. parasites, pesticides and loss of flowering plant diversity) (Potts et al., 2010; Hall and Steiner, 2019). However, that 
is not the case for most of the contemporary environmental problems related to insects. The effects of well-known environmental stressors (so called drivers of global change), such as increased $\mathrm{CO}_{2}$ and global warming, have been extensively studied in controlled (e.g. lab) and field conditions (Bidart-Bouzat and Imeh-Nathaniel, 2008; Scherber et al., 2013). However, many other stressors are relatively less studied. For instance, synthetic chemicals (e.g. pesticides) have been known to affect non-target insect species since long ago (Ware, 1980; Pimentel, 1995). Yet, only recently have been considered as significant drivers of global change (De Laender et al., 2016; Bernhardt et al. 2017; Sánchez-Bayo and Wyckhuys, 2019) and their interactions with ecosystem processes are starting to be unravelled (Schäfer et al., 2007).

The studies on the responses of insects to environmental stressors are still scarce and the majority of them have focused on numerical declines without analysing the underlying mechanisms (Kaunisto et al., 2016). Besides, most studies carried out at large scale considering community dynamics in responses to changes in the environment often overlook the responses at the individual level (Todgham and Stillman, 2013; Schulte, 2014). The mechanistic basics of responses to stressors are still poorly understood (Kaunisto et al., 2016) and this is further aggravated by emerging environmental stressors in managed and natural ecosystems (e.g. pollution and biological invasions) caused mainly by human activities (Todgham and Stillman, 2013). Although some authors have started to point out the physiologically-related causes of the sensitivity of insects to stressors (Klein et al., 2017), this is still a topic highly disregarded for the vast majority of extant insect species (Kaunisto et al., 2016; Urban et al., 2016).
Environmental Stressors. Environmental stressors can be defined as factors that hinder the achievement of optimal condition, either by acting as constraints (in relation to biological demand) or by causing detrimental effects on organisms because of increased or extended exposure (Schulte, 2014; Freedman, 2015). A range of biotic and abiotic factors can be included in such definition: from climatic stressors (e.g. temperature and humidity (Sinclair et al., 2003; Musolin, 2007), up to biological (e.g. trophic interactions and competition (McCauley et al., 2011; Adamo et al., 2013; Gutiérrez et al., 2020a) and chemical stressors (e.g. heavy metals and pesticides (Tchounwou et al., 2012; Bohnenblust et al., 2013; Gutiérrez et al., 2016; Gutiérrez et al., 2017a; Gutiérrez et al., 2017b; Gutiérrez et al., 2020b; Bernhardt et al., 2017). Moreover, these evidently bear the potential to affect all living organisms, from bacteria to vertebrates, and their associated ecosystem functions and processes.

It has been recognized that in natural conditions, organisms rarelyexperienceoptimalenvironments because biotic and abiotic factors fluctuate at a moderate extent (Steinberg, 2012; Wingfield, 2013). During their lifetime, organisms are often exposed to a variety of environmental stressors that would not be experienced individually, but rather in a mixture that interact in complex and dyamic ways (Schulte, 2014; Côté et al., 2016).

The need for experimentally addressing the effects of the interacting stressors stressor was recognized several decades ago (Breitburg et al. 1998) and nowadays is considered a topic of substantial importance for ecosystem management and conservation (Todgham and Stillman, 2013; Craig et al., 2017). 
¿How do organisms respond to environmental stressors?. Environmental stressors can, depending on their magnitude and intensity, trigger a variety of response reactions in living organisms (Figure 1) (Pimentel, 1994; Koolhaas et al., 2011). In essence, organisms would try to maintain stability through change (Romero 2004), that is to say; they to say, they would try to (at least partially) compensate for fitness reduction caused by a harsh environment (Schulte, 2014). And such responses can span through several levels of biological organization, from behaviour to physiology, morphology and ultimately the genome (Kassahn et al. 2009; Gutiérrez et al., 2020a).

Within the organisms' machinery for facing environmental stressors, some traits may remain unchanged while others can be highly plastic. Usually, physiological and behavioral traits (considered at the individual level) are more prone to quick response as they can be modified in a short time-scale, conversely to morphological traits that would require a considerable longer time to respond to the environmental cues (Padilla and Adolph, 1996; Gutiérrez et al., 2020b).

Some organisms may employ a mechanism termed canalization, through which they achieve a consistent phenotype regardless of the stress imposed by the environment (Waddington, 1942; Debat and David, 2001).

While traits important to fitness are considered to be strongly canalized (Stearns and Kawecki, 1994), in some cases, this "response" (or the lack of it), can be simply the "insensitivity of a character to environmental factors" (Wagner et al., 1997). However, canalization is only considered advantageous in homogeneous and stable environments as the development of consistent phenotypes regardless of environmental changes (e.g. stressors) may be maladaptive (Zabinsky et al., 2018).

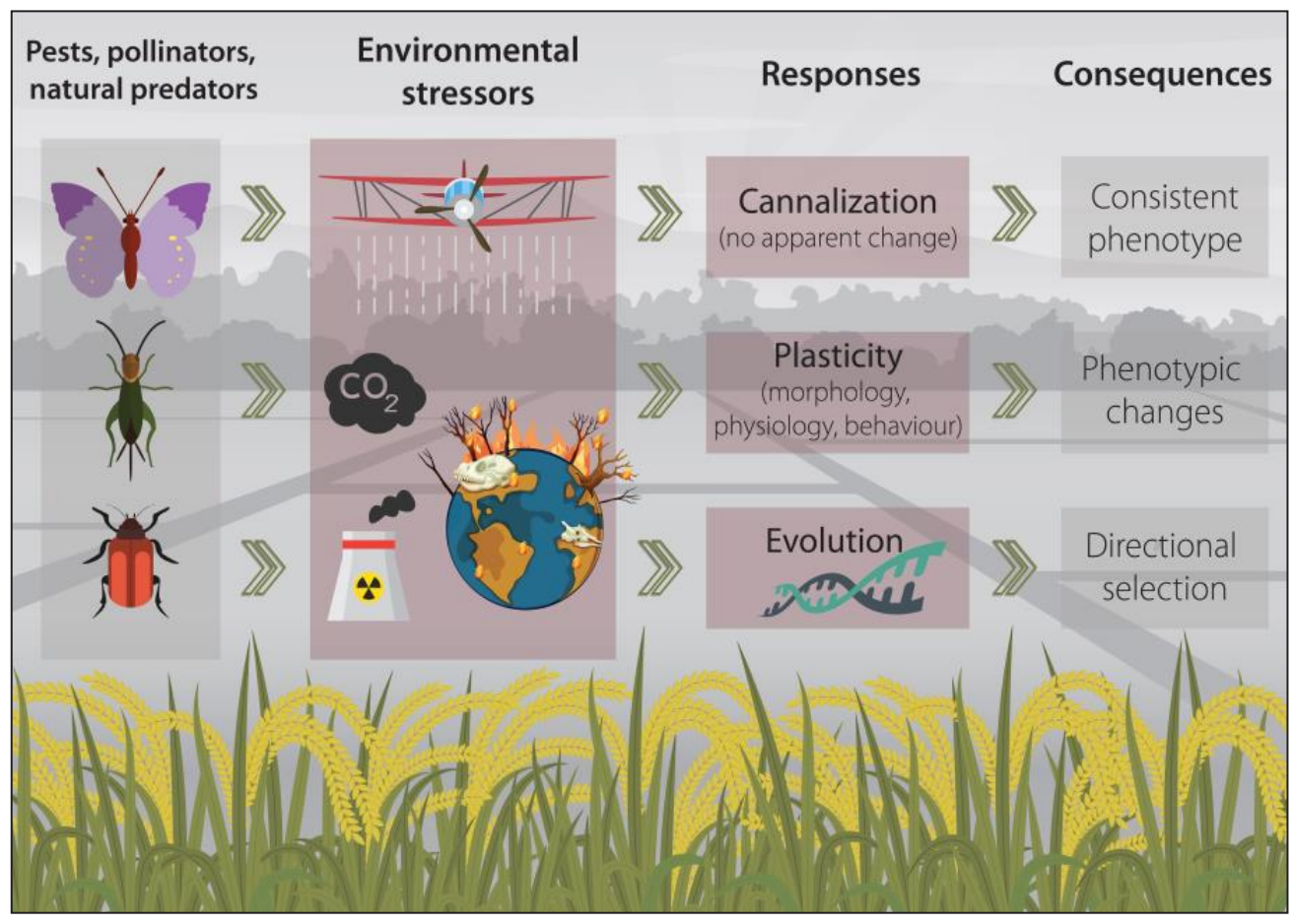

Figure 1. Conceptual figure of the mechanisms that agricultural insects may employ when facing common environmental stressors in agroecosystems. 
A second mechanisms for coping with stressors occurring within an organism's lifetime is phenotypic plasticity (Gabriel, 2005; Schulte, 2014).Whichimpliesthemodificationbehavioral, behavioural, physiological, morphological and developmental traits to successfully overcome changes in the environment (Callahan et al., 1997). Classical examples of plastic responses are the morphological and behavioural changes in Daphnia (Cladocera, Daphniidae) induced by predator-induced stress (Boersma et al., 1998), and the capability of Schistocerca gregaria (Orthoptera, Acrididae) to generate three types of polyphenism (which implies morphological and physiological changes) depending on environmental and visual cues (Tanaka et al., 2016).

It is important to consider that the distinction between canalization and plasticity can be challenging because some traits may remain stable as they are buffered by a different mechanism in an attempt to maintain homeostasis (therefore, plasticity could only be traced by monitoring multiple components of the phenotype). Moreover, living organism may simply opt for remaining unchanged despite the challenges imposed by the environment (Wagner et al., 1997). On the other hand, some organisms are "compelled" to remain unchanged simply because they may have a very limited plastic capacity (DeWitt et al., 1998), such "limitation" is thought to be (at least partially) explained by genotype (Metcalfe and Monaghan, 2001).

Finally, as a third mechanism, organisms can respond to the stress imposed by the environment through evolution. In this scenario, the environment would drive the selection pressure for the development of population divergence and even speciation (Bijlsma and Loeschcke, 2005; Lexer and Fay, 2005). A common example of this type of directional selection (in the context of environmental stressors) is the evolved resistance to antibiotics, heavy metals and pesticides (Davies and Davies, 2010; Gutiérrez et al., 2019).

The evolution of mechanisms to overcome environmental stressors (e.g. pesticides) may provide the means to survive and reproduce in hostile environments (e.g. highly managed agroecosystems) (Ffrench-Constant et al., 1999; Gutiérrez et al., 2020b). However, such mutations commonly have associated negative consequences for the fitness of the species due to physiological trade-offs (Coustau and Chevillon, 2000; Haubruge and Arnaud, 2001).

Outlook and recommendations. Although some studies have attempted to model responses to stressors based on other known effects or biological traits (Baird and Van den Brink, 2007; Haddad et al., 2008; Diamond et al., 2011). Experimental data, especially for interacting factors, is still much needed as it has been pointed out that biological responses are difficult to predict (Davis et al., 1998; Angert et al., 2011). For instance, some empirical studies have demonstrated the complex interactions that environmental stressors can exhibit, from additive and synergistic, to antagonistic and even reversed (Jackson et al., 2016).

While studying the effects of multiple stressor is challenging due to operational constraints (resources, space and workload), it remains as the most reliable way to elucidate the complex interaction of the studied factors (Todgham and Stillman, 2013; Schulte, 2014; Côté et al., 2016).

Furthermore, it is fundamental to study the responses to stressors in long-term experiments (relative to the life cycle of the model organism) as the sensitivity or responsiveness of the organisms may vary according to the life stage (Metcalfe and Monaghan, 2001). It would be interesting to undertake further research in two 
contrasting, yet complementary, directions: 1) more controlled and mechanistic approaches to understand and unravel effects of environmental stressors at the individual level. 2) A larger scaled multi-species approach to study effects that can scale up to the community and ecosystem level (mainly related to structural and functional attributes).

\section{CONCLUSION}

Understanding insect responses and the mechanisms involved (e.g. plasticity and evolution) would provide the necessary tools to dissect environmental (e.g. biodiversity loss), economic (e.g. pests and insecticide resistance) and public health (e.g. insect-borne diseases) problems given that stressors may ultimately affect ecosystem functions and processes (Christensen et al., 2006). Additionally, as mentioned above, plasticity exhibited by living organisms can significantly affect ecological patterns and processes (Miner et al., 2005). Therefore, it would be expected that community dynamics, food webs and ecosystem processes are responsive to change in, for instance, behavior and resource investment of particular species. Besides, studying the response as a whole of synthetic and natural communities to interacting environmental stressors is a promising line of research (Steinberg, 2012; Craig et al., 2017).

Conflict of interest: The authors declare that there is no conflict of interest.

\section{BIBLIOGRAPHICAL REFERENCES}

Adamo, S.A.; Kovalko, I.; Mosher, B. (2013). The behavioural effects of predator-induced stress responses in the cricket (Gryllus texensis): the upside of the stress response. J Exp Biol. 216: 4608-4614.

Angert, A.L.; Crozier, L.G.; Rissler, L.J.; Gilman, S. E.; Tewksbury, J. J.; Chunco, A. J. (2011). Do species' traits predict recent shifts at expanding range edges? Ecol Lett. 14: 677-689. doi: https://doi. org/10.1111/j.1461-0248.2011.01620.x

Baird, D.J.; Van den Brink, P.J. (2007). Using biological traits to predict species sensitivity to toxic substances. Ecotoxicol. Environ Saf 67:296-301

Barsics, F.; Caparros Megido, R.; Brostaux, Y.; Barsics, C.; Blecker, C.; Haubruge, E.; Francis, F. (2017). Could new information influence attitudes to foods supplemented with edible insects? Br Food J. 119: 2027-2039

Bebber, D.P.; Holmes, T.; Gurr, S.J. (2014) The global spread of crop pests and pathogens. Glob Ecol Biogeogr. 23: 1398-1407

Bernhardt, E.S.; Rosi, E.J.; Gessner, M.O. (2017) Synthetic chemicals as agents of global change. Front Ecol Environ. 15: 84-90

Bidart-Bouzat, M.G.; Imeh-Nathaniel, A. (2008) Global change effects on plant chemical defenses against insect herbivores. J Integr Plant Biol. 50: 1339-54. doi: https://doi.org/10.1111/j.17447909.2008.00751.x

Bijlsma, R.; Loeschcke, V. (2005). Environmental stress, adaptation and evolution: an overview. J. Evol. Biol. 18:744-749

Boersma, M.; Spaak, P.; De Meester, L. (1998) Predator-mediated plasticity in morphology, life history, and behavior of Daphnia: the uncoupling of responses. Am Nat. 152: 237-248.

Bohnenblust, E.; Egan, J.F.; Mortensen, D.; Tooker, J. (2013). Direct and indirect effects of the synthetic-auxin herbicide dicamba on two lepidopteran species. Environ Entomol. 42: 586594.

Breitburg, D.L.; Baxter, J.W.; Hatfield, C.A.; Howarth, R. W.; Jones, C. G.; Lovett, G. M.; Wigand, C. (1998). Understanding effects of multiple stressors: ideas and challenges. In: Pace M.L., Groffman P.M. (eds). Successes, Limitations, and Frontiers in Ecosystem Science. New York, NY: Springer. doi: https://doi. org/10.1007/978-1-4612-1724-4_17

Callahan, H.S.; Pigliucci, M.; Schlichting, C.D. (1997) Developmental phenotypic plasticity: where ecology and evolution meet molecular biology. Bioessays. 19: 519-525. 
Gutierrez et al.- Response of insects to environmental stressors.

Cardinale, B.J.; Duffy, J.E.; Gonzalez A.; Hooper, D.; Perrings, C., Venail, P.; Narwani, A.; Mace, G.; Tilman, D.; Wardle, D.; Kinzig, A.; Daily, G.; Loreau, M.; Grace, J.; Larigauderie, A.; Srivastava, D.; Naeem, S. (2012). Biodiversity loss and its impact on humanity. Nature. 486:59

Christensen, M.R.; Graham, M.D.; Vinebrooke, R.D.; Findlay, D. L.; Paterson, M. J.; Turner, M. A. (2006). Multiple anthropogenic stressors cause ecological surprises in boreal lakes. Glob Chang Biol. 12: 2316-2322. doi: https://doi. org/10.1111/j.1365-2486.2006.01257.x

Costanza, R.; Kubiszewski, I.; Ervin, D.; Bluffstone, R.; Boyd, J.; Brown, D.; Chang, H.; Dujon, V.; Granek, E.; Polasky, S.; Shandas, V.; Yeakley, A. (2011). Valuing ecological systems and services. F1000 Biol Rep. 3: 14.

Côté, I.M.; Darling, E.S.; Brown, C.J. (2016) Interactions among ecosystem stressors and their importance in conservation. Proc $R$ Soc $B$ Biol Sci. 283: 20152592

Coustau, C.; Chevillon, C. (2000) Resistance to xenobiotics and parasites: can we count the cost? Trends Ecol Evol. 15: 378-383

Craig, L.S.; Olden, J.D.; Arthington, A.H.; Entrekin, S.; Hawkins, C.P.; Kelly, J.J.; Kennedy, T.; Maitland, B.; Rosi, E.; Roy, A.; Strayer, D.; Tank, J.; West, A.; Wooten, M. (2017). Meeting the challenge of interacting threats in freshwater ecosystems: A call to scientists and managers. Elem Sci Anth. 5: 72. doi: http://doi.org/10.1525/elementa.256

Davies, J.; Davies, D. (2010). Origins and evolution of antibiotic resistance. Microbiol Mol Biol Rev. 74: 417-433.

Davis, A.J.; Jenkinson, L.S.; Lawton, J.H.; Shorrocks, B.; Wood, S. (1998) Making mistakes when predicting shifts in species range in response to global warming. Nature. 391: 783 -786. doi: https://doi.org/10.1038/35842

De Laender, F.; Rohr, J.R.; Ashauer, R.; Baird, D. J.; Berger, U.; Eisenhauer, N.; Grimm, V.; Hommen, U.; Maltby, L.; Meliàn, C.; Pomati, F.; Roessink, I.; Radchuk, V.; Van, P.; Brink, V. (2016) Reintroducing environmental change drivers in biodiversity-ecosystem functioning research.
Trends in ecology \& evolution. 31(12): 905-915. doi: https://doi.org/10.1016/j.tree.2016.09.007

Debat, V.; David, P. (2001). Mapping phenotypes: canalization, plasticity and developmental stability. Trends in Ecology \& Evolution. 16: 555-561. doi: https://doi.org/10.1016/S01695347(01)02266-2

DeWitt, T.J.; Sih, A.; Wilson, D.S. (1998). Costs and limits of phenotypic plasticity. Trends in ecology \& evolution. 13:77-81. doi: https://doi. org/10.1016/S0169-5347(97)01274-3

Diamond, S.E.; Frame, A.M.; Martin, R.A.; Buckley, L.B. (2011). Species' traits predict phenological responses to climate change in butterflies. Ecology. 92:1005-1012. doi: https://doi. org/10.1890/10-1594.1

French-Constant, R.; Park, Y.; Feyereisen, R. (1999). Molecular biology of insecticide resistance. $\mathrm{Mol}$ Biol Toxic Response Taylor Fr Ciudad. 533-551: 83-90. doi: https://doi.org/10.1016/03784274(95)03470-6

Freedman, B. (2015). Ecological Effects of Environmental Stressors. USA: Environmental Science, Oxford University Press. doi: 10.1093/ acrefore/9780199389414.013.1

Gabriel, W. (2005). How stress selects for reversible phenotypic plasticity. J Evol Biol. 18: 873-883.

Gutiérrez, Y.; Bacca, T.; Zambrano, L.S.; Pineda, M.; Guedes, R. N. (2019). Trade-off and adaptive cost in a multiple-resistant strain of the invasive potato tuber moth Tecia solanivora. Pest management science. 75(6): 1655-1662. doi: https://doi.org/10.1002/ps.5283

Gutiérrez, Y.; Fresch, M.; Ott, D.; Brockmeyer, J.; Scherber, C. (2020a) Diet composition and social environment determine food consumption, phenotype and fecundity in an omnivorous insect. R Soc Open Sci. 7(4): 200100. doi: https:// doi.org/10.1098/rsos.200100

Gutiérrez, Y.; Ott, D.; Scherber, C. (2020b). Direct and indirect effects of plant diversity and phenoxy herbicide application on the development and reproduction of a polyphagous herbivore. Sci Rep. 10: 7300. doi: https://doi.org/10.1038/s41598020-64252-5 
Gutiérrez, Y.; Ramos, G.S.; Tomé, H.V.; Oliveira, E. E.; Salaro, A. L. (2017a). Bti-based insecticide enhances the predatory abilities of the backswimmer Buenoa tarsalis (Hemiptera: Notonectidae). Ecotoxicology. 26(8): 11471155. doi: https://doi.org/10.1007/s10646017-1840-1

Gutiérrez, Y.; Santos, H.P.; Serrão, J.E.; Oliveira, E.E. (2016). Deltamethrin-mediated toxicity and cytomorphological changes in the midgut and nervous system of the mayfly Callibaetis radiatus. PLoS One. 11(3): e0152383. doi: https://doi. org/10.1371/journal.pone.0152383

Gutiérrez, Y.; Tomé, H.V.; Guedes, R,N.C.; Oliveira, E.E. (2017b). Deltamethrin toxicity and impaired swimming behavior of two backswimmer species. Environ Toxicol Chem. 36:1235-1242. doi: https://doi.org/10.1002/etc.3645

Haddad, N.M.; Holyoak, M.; Mata, T.M.; Davies, K.F; Melbourne, B.A; Preston, K. (2008). Species' traits predict the effects of disturbance and productivity on diversity. Ecology letters. 11(4): 348-356. doi: https://doi.org/10.1111/j.14610248.2007.01149.x

Hall, D.M.; Steiner, R. (2019). Insect pollinator conservation policy innovations: Lessons for lawmakers. Environ Sci Policy. 93:118-128. doi: https://doi.org/10.1016/j.envsci.2018.12.026

Hallmann, C.A.; Sorg, M.; Jongejans, E.; Siepel, H.; Hofland, N.; Schwan, H.; Stenmans, W.; Müller, A.; Sumser, H.; Hörren, T.; Goulson, D.; de Kroon, H. (2017). More than 75 percent decline over 27 years in total flying insect biomass in protected areas. PloS one. 12(10): e0185809. doi: https:// doi.org/10.1371/journal.pone.0185809

Haubruge, E.; Arnaud, L. (2001). Fitness consequences of malathion-specific resistance in red flour beetle (Coleoptera: Tenebrionidae) and selection for resistance in the absence of malathion. Journal of economic entomology. 94(2): 552-557. doi: https://doi.org/10.1603/00220493-94.2.552

Jackson, M.C.; Loewen, C.J.G.; Vinebrooke, R.D.; Chimimba, C.T. (2016). Net effects of multiple stressors in freshwater ecosystems: a metaanalysis. Glob Chang Biol. 22:180-189. doi: https://doi.org/10.1111/gcb.13028

Kassahn, K.S.; Crozier, R.H.; Pörtner, H.O.; Caley, M.J. (2009). Animal performance and stress: responses and tolerance limits at different levels of biological organisation. Biol Rev. 84(2): 277-92. doi: https://doi.org/10.1111/j.1469185X.2008.00073.X

Kaunisto, S.; Ferguson, L.V.; Sinclair, B.J. (2016). Can we predict the effects of multiple stressors on insects in a changing climate? Current opinion in insect science. 17: 55-61. doi: https://doi. org/10.1016/j.cois.2016.07.001

Klein, S.; Cabirol, A.; Devaud, J.M.; Barron, A. B.; Lihoreau, M. (2017). Why bees are so vulnerable to environmental stressors. Trends in ecology \& evolution. 32(4): 268-278. doi: https://doi. org/10.1016/j.tree.2016.12.009

Koolhaas, J.M.; Bartolomucci, A.; Buwalda, B.; de Boer, S. F., Flügge, G., Korte, S. M.; Meerloa, P.; Murisong, R.; Olivieri, B.; Palanzak, P.; Richter-Levine, G.; Sgoifok, A.; Steimerj, T.; Stiedlf, O.; van Dijkh, G.; Wöhrd, M.; Fuchsb, E. (2011). Stress Revisited: a critical evaluation of the stress concept. Neurosci Biobehav Rev. 35(5): 1291-1301. doi: https://doi. org/10.1016/j.neubiorev.2011.02.003

Lexer, C.; Fay, MF. (2005). Adaptation to environmental stress: a rare or frequent driver of speciation?. J Evol Biol. 18:893-900. doi: https:// doi.org/10.1111/j.1420-9101.2005.00901.x

Losey, J.E.; Vaughan, M. (2006). The economic value of ecological services provided by insects. AIBS Bull. 56(4): 311-323. doi: https://doi. org/10.1641/0006-3568(2006)56[311:TEVOES ]2.0.CO;2

Luque, G.M.; Bellard, C.; Bertelsmeier, C.; Bonnaud, E.; Genovesi, P.; Simberloff, D.; Courchamp, F. (2014). The 100th of the world's worst invasive alien species. Biol Invasions. 16: 981-985. doi: https://doi.org/10.1007/s10530-013-0561-5

McCauley, S.J.; Rowe, L.; Fortin, M-J. (2011). The deadly effects of "nonlethal" predators. Ecology. 9(11): 2043-2048. doi: https://doi. org/10.1890/11-0455.1 
Gutierrez et al.- Response of insects to environmental stressors.

Megido, R.C.; Gierts, C.; Blecker, C.; Brostaux, Y.; Haubruge, É.; Alabi, T.; Francis, F. (2016) Consumer acceptance of insect-based alternative meat products in Western countries. Food Qual Prefer. 52: 237-243. doi: https://doi. org/10.1016/j.foodqual.2016.05.004

Metcalfe, N.B.; Monaghan, P. (2001). Compensation for a bad start: grow now, pay later? Trends Ecol Evol. 16(5): 254-260

Miner, B.G.; Sultan, S.E.; Morgan, S.G.; Padilla, D. K.; Relyea, R. A. (2005). Ecological consequences of phenotypic plasticity. Trends Ecol Evol 20(12): 685-692. doi: https://doi.org/10.1016/j. tree.2005.08.002

Musolin, D.L. (2007). Insects in a warmer world: ecological, physiological and life-history responses of true bugs (Heteroptera) to climate change. Global Change Biology. 13(8): 15651585. doi: https://doi.org/10.1111/j.13652486.2007.01395.x

Oerke, E-C. (2006). Crop losses to pests. The Journal of Agricultural Science. 144(1): 31-43. doi: https://doi.org/10.1017/S0021859605005708

Padilla, D.K.; Adolph, S.C. (1996). Plastic inducible morphologies are not always adaptive: the importance of time delays in a stochastic environment. Evol Ecol. 10:105-117. https://doi. org/10.1007/BF01239351

Pimentel, D. (1995). Amounts of pesticides reaching target pests: environmental impacts and ethics. Journal of Agricultural and environmental Ethics. 8(1): 17-29. doi: https://doi.org/10.1007/ BF02286399

Pimentel, D. (1994). Insect population responses to environmental stress and pollutants. Environmental Reviews. 2(1): 1-15. doi: https:// doi.org/10.1139/a94-001

Pimentel, D.; Zuniga, R.; Morrison, D. (2005). Update on the environmental and economic costs associated with alien-invasive species in the United States. Ecol Econ. 52(3): 273-288. doi: https://doi.org/10.1016/j.ecolecon.2004.10.002

Potts, S.G.; Biesmeijer, J.C.; Kremen, C.; Neumann, P.; Schweiger, 0.; Kunin, W. E. (2010). Global pollinator declines: trends, impacts and drivers.
Trends in ecology \& evolution. 25(6): 345-353. doi: https://doi.org/10.1016/j.tree.2010.01.007

Romero, L.M. (2004). Physiological stress in ecology: lessons from biomedical research. Trends Ecol Evol. 19(5): 249-255. doi: https://doi. org/10.1016/j.tree.2004.03.008

Sánchez-Bayo, F.; Wyckhuys, K.A.G. (2019). Worldwide decline of the entomofauna: A review of its drivers. Biol Conserv. 232: 8-27. doi: https:// doi.org/10.1016/j.biocon.2019.01.020

Schäfer, R.B.; Caquet, T.; Siimes, K.; Mueller, R.; Lagadic, L.; Liess, M. (2007). Effects of pesticides on community structure and ecosystem functions in agricultural streams of three biogeographical regions in Europe. Science of the Total Environment. 382(2-3): 272-285. doi: https:// doi.org/10.1016/j.scitotenv.2007.04.040

Scherber, C.; Gladbach, D.J.; Stevnbak, K.; Karsten, R. J.; Schmidt, I. K.; Michelsen, A.; Rost, K.; Klaus, A.; Larsen Teis, S.; Mikkelsen, N.; Beier, C.; Christensen, S. (2013). Multi-factor climate change effects on insect herbivore performance. Ecology and evolution. 3(6): 1449-1460. doi: https://doi.org/10.1002/ece3.564

Schulte, P.M. (2014). What is environmental stress? Insights from fish living in a variable environment. Journal of Experimental Biology. 217(1): 23-34. doi: https://doi.org/10.1242/jeb.089722

Sinclair, B.J.; Vernon, P.; Klok, C.J.; Chown, S.L. (2003). Insects at low temperatures: an ecological perspective. Trends in Ecology \& Evolution. 18(5): 257-262. doi: https://doi.org/10.1016/S01695347(03)00014-4

Smith, K.G. (1973). Insects and other arthropods of medical importance. London: British Museum (Natural History).

Stearns, S.C.; Kawecki, T.J. (1994). Fitness sensitivity and the canalization of life-history traits. Evolution (N Y). 48(5): 1438-1450. doi: https:// doi.org/10.1111/j.1558-5646.1994.tb02186.x

Steinberg, C.E.W. (2012). Multiple stressors as environmental realism: synergism or antagonism. In: Stress Ecology. pp. 295-309. Dordrecht: Springer. doi: https://doi.org/10.1007/978-94007-2072-5_11 
Tanaka, S.; Harano, K.; Nishide, Y.; Sugahara, R. (2016). The mechanism controlling phenotypic plasticity of body color in the desert locust: some recent progress. Curr Opin insect Sci. 17: 10-15. doi: https://doi.org/10.1016/j.cois.2016.05.011

Tchounwou, P.B.; Yedjou, C.G.; Patlolla, A.K.; Sutton, D.J. (2012). Heavy metal toxicity and the environment. In: Luch A. (eds). Molecular, Clinical and Environmental Toxicology. Experientia Supplementum, vol 101. Basel: Springer. doi: https://doi.org/10.1007/978-3-7643-8340-4_6

Todgham, A.E.; Stillman, J.H. (2013). Physiological responses to shifts in multiple environmental stressors: relevance in a changing world. Integr Comp Biol. 53: 539-544.

Urban, M.C.; Bocedi, G.; Hendry, AP.; Mihoub, J.B.; Pe'er, G.; Singer, A.; Bridle, J. R.; Crozier, L. G.; De Meester, L.; Godsoe, W.;. Gonzalez, A.; Hellmann, J. J.; Holt, R. D.; Huth, A.; Johst, K.; Krug, C. B.; Leadley, P. W.; Palmer, S. C. F.; Pantel, J. H.; Schmitz, A.; Zollner, P. A.; Travis, J.M.J. (2016). Improving the forecast for biodiversity under climate change. Science. 80 (353): aad8466. doi: $10.1126 /$ science.aad8466

Van Huis, A. (2013). Potential of insects as food and feed in assuring food security. Annu Rev Entomol. 58: 563-583. doi: https://doi.org/10.1146/ annurev-ento-120811-153704

Waddington, C.H. (1942). Canalization of development and the inheritance of acquired characters. Nature. 150: 563- 565. doi: https:// doi.org/10.1038/150563a0

Wagner, G.P.; Booth, G.; Bagheri-Chaichian, H. (1997) A population genetic theory of canalization. Evolution (N Y). 51(2): 329-347. doi: https://doi. org/10.1111/j.1558-5646.1997.tb02420.x

Ware, G.W. (1980). Effects of pesticides on nontarget organisms. In: Gunther, F.A.; Gunther J.D. (eds) Residue Reviews. vol 76. New York, NY:.Springer. doi: https://doi.org/10.1007/978-1-4612-61070_9

Weisser, W.W.; Siemann, E. (2008). The various effects of insects on ecosystem functioning. In: In: Weisser W.W., Siemann, E. (eds) Insects and Ecosystem Function. Ecological Studies (Analysis and Synthesis), vol 173. Berlin, Heidelberg: Springer. https://doi.org/10.1007/978-3-54074004-9_1

Wingfield, J.C. (2013). Ecological processes and the ecology of stress: the impacts of abiotic environmental factors. Funct Ecol. 27:37-44.

Zabinsky, R.A.; Mason, G.A.; Queitsch, C.; Jarosz, D.F. (2018). It's not magic-Hsp90 and its effects on genetic and epigenetic variation. Seminars in cell \& developmental biology. 88:21-35. doi: https:// doi.org/10.1016/j.semcdb.2018.05.015

Zalucki, M.P.; Shabbir, A.; Silva, R.; Adamson, D.; Shu-Sheng, L.; Furlong, M. J. (2012). Estimating the economic cost of one of the world's major insect pests, Plutella xylostella (Lepidoptera: Plutellidae): just how long is a piece of string? J Econ Entomol. 105(4): 1115-1129. 